\title{
11
}

\section{Europeanization and the Varying Responses in Collective Skill Systems}

Justin J.W. Powell and Christine Trampusch ${ }^{1}$

\section{Introduction}

Europeanization elicits varying responses in collective skill systems, which are still mainly governed in national contexts and determined primarily by collaboration and conflicts within them. This chapter explores the impact of European developments, particularly the European Union (EU), on institutional change in vocational training regimes. The aim is twofold: first, to investigate the impact of the European level on national institutions responsible for skill formation; and second, to explore similar challenges but varying responses to European initiatives of the collective skill systems analyzed in this book. To what extent and in which directions are Europe-wide processes affecting the collective skill systems in Austria, Denmark, Germany, the Netherlands, and Switzerland? This question is important because these systems share certain characteristics but differ in their institutionalization pathways and the degree to which the influence of the EU has grown in education and training. To answer this question, we investigate the two levels and their interaction in countries in which conflicts over such forms of Europeanization have ensued-Germany and Switzerland-as well as those in which consensus has facilitated Europeanization-Austria, Denmark, and the Netherlands.

For decades, vocational education and training (VET) policy was an autonomous domain of $\mathrm{EU}$ member states, leaving little room for a common EU policy. However, we argue that the past decade has witnessed a transformation. Within the EU, the reform of skill formation systems has been advanced by the Lisbon strategy- "to make the European economy the most dynamic and competitive knowledge-based economy in the world" (European Council, 
2003). Since 1999 and 2002, the Bologna and Copenhagen processes in higher education (HE) and VET, respectively, have articulated these overarching goals in European skill formation.

The Bologna Process that has induced reforms in national HE systems exemplifies how even those domestic institutions and politics that are actively shielded from external influence have been and are increasingly affected by initiatives developed at the EU level and carried out throughout Europeand beyond. In Copenhagen, in November 2002, thirty-three ministers of education from EU member and nonmember states as well as the European Commission (EC) adopted guidelines to strengthen cooperation in VET in order to promote mobility across national labor markets and to enhance the competitiveness of the European Union, especially vis-à-vis the United States. The Copenhagen Process has led to efforts to introduce a European Qualifications Framework (EQF) as well as a European Credit System for Vocational Education and Training (ECVET). The objective of both instruments is to develop common descriptors and standardized assessments of qualifications that can be applied to all educational systems. Their underlying principle is the orientation to learning outcomes and the development of National Qualifications Frameworks (NQFs), which correspond to the description of qualifications laid down in the EQF. These initiatives are not explicit mechanisms for the harmonization of vocational qualifications, but rather acknowledge national specificities in VET systems while providing standardized ways of defining and measuring qualifications. De facto, the EU initiatives promote market making by soft governance and without any transfer of competencies and sovereignty to the EU (Trampusch, 2008: 591-2). Although the EQF is a voluntary framework with no formal legal obligations for national governments, both members of the EU and nonmember states have formulated NQFs, which build upon the principles set forth in the EQF initiative. We observe evidence of Europeanization, understood as the effects of EU policies and programs on national VET systems, yet to varying degrees across Europe.

Especially in countries with collective skill formation systems, the EQF principle of learning outcomes instead of vocational orientations poses a serious challenge because it is at odds with the normative and political logics that underpin them. This is so because, by their very nature, the EU initiatives promote not only the increase of permeability between general, vocational, and higher education, but also modularization and standardization (Trampusch, 2009: 378; Powell and Solga, 2010). The principle of increasing permeability challenges collective skill formation systems because some stakeholders of vocational training fear losing ground in competition with higher education institutions. Modularization demands the dividing up into component parts of what is considered comprehensive vocational capability - the vocational principle or Berufsprinzip (see, e.g., 
Deißinger, 1994; Kraus, 2007)—upon which the strength and uniqueness of collective skill formation systems are founded.

Because of this particular challenge, which mirrors considerable misfit between EU initiatives and persistent national systems, countries with collective skill formation systems may be viewed as least likely cases (Eckstein, 1975) for Europeanization effects. ${ }^{2}$ In these countries, national VET systems have been gradually transformed by globalization, demographic shifts, educational reforms in neighboring organizational fields, and by a variety of European and national policy initiatives (Powell and Solga, 2010). However, because the "vocational principle" fundamentally contradicts the "learning outcomes" approach of the EU initiatives, we might expect that these would have no or very little influence on vocational training in collective skill system countries. Nevertheless, even in these countries, national VET systems are being gradually transformed because of recent EU initiatives and national reactions to them.

In our analysis, we observe two different trajectories of Europeanization. In Denmark, the Netherlands, and Austria, the EQF initiative sped up ongoing reform discussions and the processes of establishing NQFs exhibit relative consensus. By contrast, in Switzerland and Germany, domestic discussions about the NQFs have been far more conflictual, even polarized. Our study leads us to hypothesize that the EU initiatives in vocational training will increasingly impact national training regimes in Europe-even those least likely to easily adopt and implement European VET policies.

The study of Europeanization should apply a multilevel perspective that leaves enough room for the study of domestic politics, which is obviously important in education and training as these remain well within the authority of nation states. This perspective has several merits. First, it emphasizes the roles of actors and how actors and their behavior are constructed in the course of EU policy implementation, which establishes new opportunity structures in domestic reform arenas by shifting power constellations. Second, it acknowledges that national VET systems are far from being static regimes; they undergo processes of change and reform independently of the European Union (Trampusch, 2009: 372-3). It is important to consider the dynamics of national reform processes because the EU impact on national systems "is contingent on whether a country is already involved in a process of reform or not" (Radaelli, 2000: 22). ${ }^{3}$ By applying a sequence-oriented perspective, we reconstruct how processes of Europeanization that exhibit varying speed and strength have played out in the countries with collective skill formation systems.

In methodological terms, this chapter is explorative. It applies the method of process tracing (Mahoney, 2004) in a straightforward manner. We trace the longer-term processes of Europeanization and contrast that historical sketch with contemporary analysis of how domestic actors have reacted to $\mathrm{EU}$ 
initiatives. In this chapter, we show how the characteristics of collective skill formation systems mediate the effects of the European Union and Europe-wide initiatives and investigate the varying national responses. Contrasting case studies enable us to reconstruct differences and similarities in institutional change among the collective skill regimes. This analysis provides linkages to the country chapters, which provide more historical detail on each of the countries analyzed here.

\section{EU initiatives in vocational training}

In this section, we provide a short overview of the history of EU initiatives in the domain of vocational training and focus especially on the EQF and ECVET initiatives in order to explain why EQF and ECVET may be at odds with the foundational principles of collective skill formation systems. Whereas education has traditionally been and remains controlled mainly by national governments, the $\mathrm{EU}$ and its predecessors have long looked to vocational training - which is of explicit, considerable, and direct relevance for the European Economic Community - as a policy arena in which to facilitate European cooperation. Over time, the EC/EU has elaborated a variety of instruments, such as the exchange of information and individuals, dissemination of research and recommendations (especially through its VET think tank CEDEFOP), and even directives (Anerkennungsrichtlinien), to reach its supranational objectives. Here, we distinguish EU policies in skill formation prior to and after the Maastricht Treaty of 1992, a watershed event (see Walkenhorst, 2008 on the expansion and integration of education policy over the postwar period).

\section{EU policy until Maastricht: From coal and steel to Maastricht}

Even the original Treaty of Paris of 1953 to establish the European Coal and Steel Community (ECSC) had an article (Art. 56) with a skill formation dimension, namely that the ECSC should finance employee retraining. In 1957, the Treaties of Rome were much more explicit, as the EEC Treaty aimed to coordinate activities in VET and research (Art. 41), to foster educational and employment exchange programs (Art. 50), to mutually recognize exam diplomas and qualifications (Art. 57), to strengthen cooperation in and mutual recognition of technical and further education (Art. 118), and to improve knowledge of European culture and history (Art. 128), albeit via general principles to guide implementation of a common VET policy (see Gillingham, 2003). Thus, from the very beginning, skill formation was integral to the vision of European communities. 
In the 1970s, the education ministers in the Council of Ministers began to meet and call for a variety of action programs, beginning with general guidelines for a VET action program (1971) and followed by the Janne Report, which called for Community policy on education by linking education and economy as a justification for the inclusion of education in future EC policy (1973), and by the founding of a Directorate-General for Research, Science \& Education (DG 12). Education was to have a "European dimension," avoid nationalism, and respect national structures and traditions while simultaneously promoting necessary "harmonization." As a result, the ministers of education in 1974 passed the Resolution on Cooperation in Education, which set forth the fundamental principles: (a) educational cooperation should occur in accord with gradual harmonization of economic and social policy in the EC; (b) education must not be taken as only part of economic life; and (c) each country's traditions should be considered (harmonization is not a goal in and of itself). The concrete action areas defined here aimed to improve cultural and vocational education and to create transparency among European educational systems. Comparable European statistics and documents were to be gathered; cooperation among higher educational institutions was to be advanced; and recognition of educational certificates was to be enhanced. Last, cooperation was to promote mobility among researchers, teachers, and students through better language education and to create more equal opportunities through full access to all forms of education.

By the end of 1976, the Community Action Program had begun, a permanent Education Committee had been established, and an action area to "improve the connections between the educational systems in Europe" had been defined. Soon thereafter, the Eurydice information network began, as did the NARIC network (1984-2006) that sought to improve the cross-border academic recognition of diplomas and periods of study, and diverse action programs aimed at increasing student mobility and study visits (ERASMUS, ARION, COMETT).

In the attempt to enhance mobility by finding a joint analytic description for skills earned in VET systems, European directives for recognizing learning pathways and certificates were devised (Anerkennungsrichtlinien); however, this orientation led to the valuation of school-based training and higher education above that of in-firm training-a considerable problem for Germany with its master craftsman or Meister; consequently, Germany strongly criticized this proceeding (Trampusch, 2008: 587). Because the recognition of VET certificates raises serious methodological and legal issues and because transparency between the distinctive models of VET systems-such as the German, English, and French-cannot be achieved solely on the basis of such recognition, the European Council favored the process of finding equivalents via the documentation of overlapping vocational qualifications (Trampusch, 2008: 586). Even this prompted resistance in some member states. 
In sum, the period prior to Maastricht encompassed a wide array of resolutions, expanding programs to encourage cross-border exchanges and network building, and even the general principles for the implementation of common VET policy to guarantee adequate training for all. Yet in the Maastricht Treaty, the principle of subsidiarity and a ban of "harmonization" were codified because the member states sought to limit the authority of the Commission in education policy (Balzer and Rusconi, 2007: 62). Partially in response, after Maastricht, significant soft-law mechanisms under the label "open method of coordination" (OMC) have become commonplace: ironically, it is these less coercive governance mechanisms that achieve the goals of Europeanization on a largely voluntary basis. Given the decade-long experiments and programs, this development promised a way out of stalemate, at least potentially. Furthermore, the explicit harmonization prohibition included in the Maastricht Treaty also did not result in the Commission taking on a less activist role (for details, see Walkenhorst, 2008; Borrás, 2009). In fact, the opposite has been the case.

\section{EU policy after Maastricht}

In the mid-1990s, after Maastricht, the Commission was emboldened and turned to soft governance as its policy ideals shifted to the economic aims of competitiveness and innovation. Soft governance leaves room for multilevel games and creates opportunity structures enabling domestic actors to use $\mathrm{EU}$ initiatives to overcome domestic veto-points and veto-actors. Such governance helps domestic actors legitimate their own domestic priorities and preferences. Although the many European initiatives in skill formation paved the way, the post-Maastricht shift from mechanisms of direct control that risk confrontation to indicator comparison is of particular importance for the achievement of education and training goals of recent decades, especially visible in the Bologna and Copenhagen processes that institutionalize common ideals and goals across Europe and beyond (Powell et al., forthcoming).

While the 1997 Amsterdam Treaty modified the Maastricht Treaty to give the European Parliament greater influence over decision-making in VET, the most important shift came a year later when the education ministers of France, Germany, Italy, and the United Kingdom issued the Sorbonne Declaration on the "harmonization of the architecture of the European higher education system." This statement speaks about an "open area for higher learning" that requires "continuous efforts to remove barriers and to develop a framework for teaching and learning, which would enhance mobility and an even closer cooperation." A year later, the Bologna Declaration on the European Higher Education Area specified much more clearly the ramifications of the past and future policies aiming to "Europeanize" education and training. 
The Bologna Process is of significance especially for the collective skill systems analyzed here because of the historic division and competition between the two major sectors in skill formation and the changes that this first process of Europeanization has already brought to bear on HE and VET systems (see Powell and Solga, 2010, 2011).

At the Lisbon summit in the year 2000, the program "Education and Training 2010" was conceived to integrate the diverse actions in the fields of education and training at the European level, including HE and VET. EU leaders set out a new strategy, based on a consensus among member states, to modernize Europe: The Union must become the "most competitive and dynamic knowledge-based economy in the world capable of sustainable economic growth with more and better jobs and greater social cohesion" (European Council, 2000). To achieve this ambitious goal, the heads of state and of government who gathered in Lisbon asked for not only "a radical transformation of the European economy" but also "a challenging program for the modernizing of social welfare and education systems" (European Council, 2000: 2). In 2002, they went on to say that, by 2010, Europe should be the world leader in terms of the quality of its education and training systems. The "Copenhagen Process" focuses on innovation in skill formation as a means in and of itself and also to enhance global (economic) competitiveness. For many countries, the Copenhagen Process will mean a fundamental transformation of education and training carried out in each country according to national contexts and traditions. It will be driven forward by cooperation between member states at the European level through sharing experiences, working toward common goals, and learning from what works best elsewhere via the OMC (e.g., Falkner et al., 2005). The Education Council and the Commission endorsed a decade-long work program to be implemented via OMC. These agreements constitute a new and more coherent strategic framework of cooperation for the Community in the fields of education and training. Thus, we next discuss the evolution of the Copenhagen Process, its major goals, and the EQF and ECVET initiatives in particular as sources of both exogenous pressures and conflicts among a myriad stakeholders within countries.

\section{The Copenhagen Process}

The so-called Copenhagen Process was launched as the contribution of VET to the challenges identified in the Lisbon strategy. The Copenhagen Declaration (2002) was approved by thirty-three participating countries, including the EU member states, the EEA/EFTA countries of Iceland, Norway, and Liechtenstein (but not Switzerland), as well as candidate countries Croatia, Macedonia, and Turkey. Clearly stated, the declaration set the following 
goals: to promote mutual trust, to enhance transparency and the recognition of previously attained competencies and qualifications, to increase mobility (especially cross-border mobility, but also social), and to facilitate access to lifelong learning. The ministers who gathered in Denmark's capital identified several priorities for enhanced European cooperation in VET across Europe, including a strengthened European dimension in VET via promoted mobility of individuals; improved transparency, information, and guidance within and among national VET systems; strengthened policies and practices that support member states in developing their systems, especially concerning lifelong learning; recognition of competencies and qualifications (particular emphasis was laid on developing a set of common principles regarding validation of nonformal and informal learning); and quality assurance. These themes have been further developed at successive ministerial meetings held in Maastricht (2004), Helsinki (2006), and Bordeaux (2008), with communiqués specifying the new targets.

Within the framework of the Copenhagen Process, EU countries have begun to cooperate in elaborating several specific instruments and common standards. In terms of quality assurance, the European Quality Assurance Reference Framework (EQARF) is in development. Procedures to identify and validate prior learning (formal, nonformal, and informal) and guidance systems are being negotiated. A shift to qualifications based on learning outcomes has diffused, as has the awareness of the importance of training/learning pathways tailored to the individual. Most importantly, the EQF and the ECVET emphasize the comparative work that needs to be done in order to meaningfully measure and standardize qualifications earned throughout Europe. In the following, we focus on the political processes surrounding these potentially controversial elements of the Copenhagen Process.

The EQF was designed to facilitate the comparison of educational attainments across countries, as was the International Standard Classification of Education (ISCED)-itself in need of comprehensive revision to adequately represent European skill formation systems (see Schneider, 2008). Nevertheless, such comparisons remain highly politicized in light of the consequences of cross-nationally comparative education performance results, such as PISA and Bologna benchmarking (Münch, 2009). Such outcome comparisons have yet to dominate VET in a similar way because the disciplinary and political debates about the boundaries and relationships between competencies and skills are ongoing (Baethge et al., 2008), even as the EQF arranges qualifications vertically, by differentiating between eight stages of qualifications, and horizontally, by distinguishing between knowledge, skills, and competences.

Particularly significant for collective skill systems is that this breakdown into component parts of what is considered comprehensive vocational capability challenges the "vocational principle" upon which the strength and 
uniqueness of collective skill regimes are founded. Because they break integrated occupations down into their component skill modules, the $\mathrm{EQF}$ and the relevant NQFs have led to discussions that in turn prompt the modularization of skill systems, which further facilitates such comparisons (see also Thelen and Busemeyer in this volume).

Recent CEDEFOP studies comparing contemporary developments in NQF implementation show that the countries included here are at different stages in the process: ${ }^{4}$ whereas the Netherlands and Austria are still at the design stage, Germany has reached the testing phase, and Denmark the implementation stage (CEDEFOP, 2010: annex 2). Furthermore, CEDEFOP reports that the NQF in Germany is characterized by a comprehensive and coherent set of level descriptors, covering all subsystems and levels of education, whereas the Danish NQF is divided into two parts in which the higher levels are restricted to higher education. In Austria, the levels 6, 7, and 8 are divided in two parallel streams, one for higher education and one for vocationally oriented qualifications (Pevec Grm and Bjørnåvold, 2010b: 6), which questions Austria's successful institutionalization of a continuum of VET stretching from the secondary to the upper tertiary level with linkages and bridges between vocational and higher education pathways (see Graf, Lassnigg, and Powell in this volume). In addition, Austria and Germany are countries in which stakeholder involvement in the preparation of the NQFs has been considerable (Pevec Grm and Bjørnåvold, 2010b: 7) and has led to a good deal more active debate and heightened reflection on the choices being made and their consequences. However, as the cases of Austria and Germany show, stakeholder engagement can lead to consensus or to conflict.

In sum, if Europeanization in skill formation began with vocational training at the start of European economic cooperation, a range of further aspects have supplemented this original focus, including mutual recognition of diplomas and cooperation in higher education. Indeed, the latest themes emphasize the many scientific and political challenges brought about in attempts to standardize qualifications, competencies, and credits.

\section{The politics of Europeanization in collective skill formation systems}

As the previous section has shown, the force of the EU in education policy should no longer be regarded as marginal, as the developments are not only long-standing but also increasingly influential in the field of VET. As new governance structures have evolved in the EU, in particular with the EQF and the ECVET initiatives, the EU has explicitly challenged collective skill formation systems to reform according to overarching standards. The underlying 
principle of both initiatives is to (re-)orient systems to learning outcomes and the development of NQFs that correspond to the description of qualifications laid out in the EQF.

To reconstruct probable Europeanization effects in systems of collective skill formation, this chapter uses the concept of Europeanization as a heuristic device to provide us with an in-depth analysis of the domestic reactions to EU policies. Following Olsen (2002: 943), we apply the concept of Europeanization more as an "attention-directing device" than as an explanatory causal concept. Studies show that, although the EU mainly uses soft governance methods in education policy, such influence can nevertheless decisively affect national educational systems (see, e.g., Witte et al., 2008; Trampusch, 2009; Powell and Solga, 2010; Busemeyer and Trampusch, 2011). This phenomenon of Europeanization in education policy questions one central assumption of the skills literature up to now, namely, that national education systems and policies are independent from policymaking at supranational level. Before we analyze whether and how the EQF and ECVET initiatives have influenced VET in Austria, Denmark, Germany, the Netherlands, and Switzerland, we outline our analytical framework.

Besides the analysis of the European integration process and of the policymaking and governance structures of the EU, research on the effects of the $\mathrm{EU}$ on national systems now belongs to the core areas of inquiry in European studies (Radaelli, 2004; Börzel, 2005). In political science, Europeanization research examines the influence of the EU on domestic policies, polities, and politics. Whereas the initial wave of studies conceptualized these impacts mainly from a "top-down perspective," today most studies view Europeanization as a "bottom-up" process and integrate the dynamics of domestic politics and policymaking into the analysis of EU effects (Börzel, 2005). These studies insist that national response strategies possess a degree of maneuverability and argue that the analysis of Europeanization processes requires an exploration of actors' behavior. Increasingly, studies conceptualize Europeanization as a multilevel process and argue that domestic actors may view and use EU policies as an opportunity structure for prompting and promoting domestic reform policies, which otherwise would be hindered by national veto-players (Woll and Jacquot, 2008). From the bottom-up perspective, Europeanization is conceptualized as a process that is shaped not only by a misfit between EU and national policies (e.g., the compatibility between domestic policies and EU policies) but also by the strategies, preferences, interests, and ideas of domestic actors (Börzel, 2005; Mastenbroek and Kaeding, 2006: 331-40). Following Radaelli (2000: 22), we may also consider the dynamic of national reform processes because, with regard to the EU impact, it makes a difference whether or not a country is already involved in reform processes. 
The conceptualization of Europeanization as a "variant of a 'two-level game'" (Putnam, 1988) is, according to Büchs (2008), particularly suitable for investigating Europeanization processes in cases of non-legally binding $\mathrm{EU}$ policies-as is the case in education policy. The education policy field is one in which the EU applies soft governance modes like the OMC and formulates objectives, but nation states are still sovereign, and the principle of subsidiarity guarantees that national political and socioeconomic actors may define and interpret EU "pressures" in ways that allow them to strategically and selectively use such pressures in domestic reform politics (Büchs, 2008: 21-2). To gauge such strategic use of Europeanization processes, indepth analysis of the strategies, preferences, interests, and ideas of domestic actors and their reactions to EU impulses offers a crucial starting point in the analysis of Europeanization (see Radaelli, 2004). Despite the likely influence of NQF implementation on even the legal basis of VET, the influence will depend on national educational and political traditions that create variance in linkages of educational subsystems, in the objectives, purposes, designs, and implementation strategies, and in the extent of stakeholder involvement in NQF discussions (Pevec Grm and Bjørnåvold, 2010b: 6). NQFs should not be mistaken for solely technical instruments. Rather, NQFs have political and social dimensions (Pevec Grm and Bjørnåvold, 2010a: 9). By their nature, they are neither neutral instruments nor evidence-based policy learning tools; rather, they have become a significant technology of EU multilevel governance (Cort, 2010a). Such EU initiatives have had and most likely will increasingly have an impact on national training regimes not only by directly initiating the NQFs processes but also by indirectly inducing change in the national vocational training institutions, for example, through enhanced modularization.

This perspective stresses the role of domestic politics in shaping Europeanization processes and acknowledges that domestic institutions, such as vocational training regimes, are not static institutions but steadily adapting to the changing external environment through institutional change. Our analysis reveals two key patterns of Europeanization in our five cases. In Germany and Switzerland, Europeanization of national training policy is contested because some domestic actors have been keen to use especially the EQF/NQF discussions as an opportunity structure in the domestic reform arena, whereas other actors oppose such usage of the EU and its initiatives. By contrast, in Austria, the Netherlands, and Denmark, Europeanization is much more consensual because there is a good fit between national reform discussions and the EU initiatives that match or even strengthen national interests and priorities (see Graf, Lassnigg, and Powell in this volume).

Given these differences, we next discuss the status of debates-or the absence thereof-among countries with collective skill systems. In particular, 
we use contrasting case studies to reconstruct the varying reactions of the domestic actors to the EQF and ECVET initiatives. However, our analysis must remain preliminary as these reforms are still underway. We show that the ways in which domestic actors react to European Union policies mirrors important differences between the collective skill formation systems analyzed here.

\section{Countries of conflict: Switzerland and Germany}

Identifying countries marked by conflict in the realm of skill formation, we observe that Switzerland and Germany are both cases where proactive political authorities and conflicts exist in the preparation processes of NQFs. Despite this similarity, however, each country follows a specific trajectory. Whereas in Switzerland the NQF process has stagnated, in Germany the preparation process has moved forward. In Switzerland, the efforts of the federal vocational training institute (Swiss Federal Office for Professional Education and Technology, BBT) to formulate an NQF have failed because of the resistance by the Swiss Gewerbe (crafts). ${ }^{5}$ By contrast, in Germany, a coalition between large employers and the Federal Ministry of Education and Research (BMBF) seems able to overcome the opposition of trade unions. Whereas in Switzerland there is stalemate due to the veto-power of the Gewerbe, in Germany the debates about the NQF have changed not only power relations but also the institutional arrangements of the policy formulation process because employers and the federal ministry successfully play a "two-level game." German employers as well as the federal government have used the discussions on an NQF and the ECVET system as a means to deregulate the German vocational training system by linking the NQF initiative with domestic discussions on modularization.

\section{SWITZERLAND}

Although Switzerland is not a member of the EU and is certainly careful to maintain its centuries-old neutrality, there is currently almost no policy field in that it has not been influenced by the EU or indeed "Europeanized" (Linder, 2011). In terms of the two sectors of skill formation, VET and HE, important differences can be found in the pace of reform and the depth of changes considered desirable.

In Swiss VET, the federal vocational training institute (BBT) and its representatives are strong supporters of the EQF and NQF (Longpré, 2007: 3), whereas the Gewerbe and the cantons remain highly skeptical, by and large. This stalemate in vocational training contrasts sharply with the high-speed adaptation processes witnessed in higher education. Among the dozens of countries now participating in the Bologna Process, Switzerland is a model 
student. Already in 2009, the representatives of the universities decided upon an NQF for HE (CRUS et al., 2009) that aims to overcome the transaction costs of locally controlled higher education institutions. Originally, representatives planned to formulate a common NQF for higher education and vocational training. However, this initiative failed because of conflicts between universities and the business camp on how to deal with the differentiation between more theoretically oriented and more applied foci in tertiary education (ISCED 5A and 5B) in the Swiss higher education system (Meyer, 2010: 15). Notably, the BBT prioritized the EQF initiative against the ECVET (BBT, 2009a: 2; $2009 b: 2$ ). The director of the vocational training division of the BBT, Hugo Barmettler, clearly states the status quo in Switzerland: "In the Copenhagen Process, we are still nowhere" (quoted in Schlenczek, 2009: 9; translation by authors).

Nevertheless, over the past several years, Switzerland has become strongly involved in European education policy (Interview $\mathrm{CH} 1$ ), both by involvement at the expert and information-exchange levels and by being a partner in several transnational projects more or less linked to the EQF initiative (Trampusch, 2010: 200-1). Similarly, the national Validacquis project develops assessments and recognition of informal competences and qualifications, which can be a strategic device used in domestic politics, as the "implementation of pilot projects will help to disseminate the information and develop a larger awareness of the key concepts [of the EQF]" (Longpré, 2007: 5). On the path toward preparing a unified NQF, the BBT, together with the Organizations of Work $(\mathrm{OdA})$, has engaged in the preparation of sectoral qualification frameworks (Bieber, 2010: 786).

Because Switzerland did not sign the Copenhagen Declaration when it was officially enacted in 2002, the country today only holds an "observer status" to this pan-European process (Bieber, 2010: 786). However, already in 2005-before the EU decided upon it-the BBT asked the Swiss VET actors to prepare official statements on a proposed EQF. The same happened in 2006 with reference to the ECVET initiative (Stalder, 2006), although the BBT is skeptical of it because of the strong and durable dual apprenticeship tradition in Switzerland (BBT, 2009b: 2).

The domestic discussion on the EQF and the Swiss NQF can be summarized as follows. First, the BBT is the driving force behind the initiative that Switzerland should follow the Copenhagen Process and engage the EQF initiative. However, the BBT has failed to overcome the resistance of the Gewerbe. Consequently, initial attempts to prepare a Swiss NQF were terminated at the start of 2008 (Interview CH7). In 2010, the BBT started a new initiative. The BBT views the Copenhagen Process as a steamroller (Antonelli Müdespacher, 2010:24) and, through development of a so-called taxonomatic model (Taxonomiemodell), has intensified its effort to speed up this process (Ibid.: 35 ). 
The taxonomatic model splits up qualifications into knowledge, skills, and the so-called "transferable competencies" that have been adapted to the Swiss vocational training context. This serves strategically as a preparatory stage for the NQF.

Second, the cantons, the small and medium enterprises (SME), the trade unions, and the professional associations have been reluctant to support the EU activism of the BBT (KV-Schweiz, 2005; Interview CH4). NQF discussions have been "highly controversial" (Interview CH1). Some stress that Switzerland, and the Gewerbe in particular, "does not need" an NQF (Interview $\mathrm{CH} 2$ ). The BBT, they claim, has proactively pushed forward the process without sufficient consultation of the stakeholders (Interview $\mathrm{CH} 2$ ). By and large, the cantons remain highly skeptical and express "a healthy lack of enthusiasm" (Interview CH3). Finally, the trade unions fear that an NQF may well have negative consequences for wage bargaining and also view the ECVET quite critically (Interview $\mathrm{CH} 4$ ).

Third, businesses show a range of positions depending on the economic sector (for the following and further sources, see also Trampusch, 2010: 200-1). Whereas globally oriented firms of the banking and financial sector as well as businesses in the hotel and gastronomic sectors-firms that recruit foreign workers-favor the EQF and ECVET initiatives (Schlenczek, 2009: 9), firms that remain more oriented to Swiss workers continue to nurse their skepticism. For example, the Association of the Swiss Mechanical and Electro Engineering Industries (Swissmem) in general welcomes but also doubts the effectiveness of the EQF. By contrast, the Gewerbe has harshly criticized both the unilateral approach of the BBT and the fact that the Schweizerischer Gewerbeverband (SGV) ${ }^{6}$ has been insufficiently incorporated in the national discussions. In its statement on the ECVET, a new lobby organization of the SME in VET policy-the Business Network for VET Questions (SQUF)-stated that the EU initiatives threaten the occupational principle and that the EQF does not fit well the traditional Swiss dichotomy between research and applied sectors in HE. It is not so with the ModuQua, a private association of which the Swiss Association for Continuing Education (SVEB) is a member, which strongly supports the EQF and the ECVET initiatives because of their support of the further modularization of training (Schläfli, 2010).

In sum, the Swiss landscape exhibits peaks and valleys regarding panEuropean reforms of skill formation, with some support for standardization in $\mathrm{HE}$ but divergent voices calling for what they consider progress as well as resistance to what proposed changes imply for the Swiss VET system. Whereas Switzerland explicitly maintains its neutrality vis-à-vis the EU, Germany has been and continues to be perhaps the major engine of the European project, despite the explicit challenge European skill formation reforms pose for its 
traditionally stratified and divided higher education and vocational training systems (Powell and Solga, 2011).

\section{GERMANY}

As an original signatory of the Bologna Process, Germany already implemented an NQF for HE in 2005 (CEDEFOP, 2009: 40). While the Federal Ministry of Education and Research (Bundesministerium für Bildung und Forschung, $\mathrm{BMBF}$ ) began a pilot initiative for the development of a credit system for VET in response to the Europe-wide ECVET initiative in 2007 (see BMBF, 2010), the NQF process has remained highly controversial, although the discussions on the NQF have progressed further than in Switzerland. In Germany, the preparation process for the NQF started in 2006. A first proposal, called "Discussion Proposal for a German Qualifications Framework for Lifelong Learning" was published in February 2009 (AK DQR, 2009). This was followed by a test phase in various sectors (health, retail, information technology, metal/electronics) that lasted until May 2010. The results have led to intensive discussions (CEDEFOP, 2009: 40; www.deutscherqualifikationsrahmen.de).

Just as in Austria, the Netherlands, and Denmark, all relevant stakeholders in Germany agreed on the EQF during the consultation process (Trampusch, 2008). However, beneath the surface, conflicts and fissures have arisen from the beginning of the NQF process (Kuda and Strauß, 2006). Georg Hanf and Volker Rein (2006: 2) argue that, in the discussion on the NQF and EQF, "very different interests have been articulated." Furthermore, experts on the German VET system claim that the principles of the EQF are at extreme odds with the main underlying logic of the German VET system, namely, the "vocational principle" or Berufskonzept (Severing, 2005: 14). Recent reforms in the VET system aim to uphold the Berufskonzept and can thus be considered solely protectionist adaptations within the system (Kraus, 2007: 385-9), such as the expansion of the "pre-vocational training system"-dubiously called the "transition system" (Übergangssystem) -that is supposed to compensate for the steady lack of training opportunities in the dual system but functions rather to "cool out" less-educated youth (Baethge et al., 2007; Solga, 2008). The most important cause of these conflicts is that large firms, their associations, and the federal government have linked the discussion on the NQF to debates on modularization and deregulation of the dual system (Trampusch, 2008). In addition, the Federal Education Minister explicitly names the NQF as a means to increase the permeability between the different national subsystems in education and training (Schavan, 2008), although it remains to be seen what effects it will have on permeability and thus on educational pathways.

The German EQF/NQF discussion has resulted in significant cleavages. Most large employers who support modularization also favor the EQF and are strongly engaged in the NQF process. The Confederation of German Employers' 
Associations (Bundesvereinigung der Deutschen Arbeitgeberverbände, $\mathrm{BDA}$ ) uses the NQF discussion to strengthen its demand for a shortening of the apprenticeship period from three to two years (Woortmann, 2006). German employers also strongly support the development of the ECVET system; they have even installed information platforms in order to advertise the instrument among employers, arguing that ECVET would enable firms to "outsource parts of initial and continuing vocational training into foreign countries" (ECVET, 2010). In contrast to the employers, the trade unions-in particular the most important ones like the Confederation of German Trade Unions (DGB), the German metalworkers' union (IG Metall), and the two teachers' and education unions (GEW and ver.di)-explicitly criticize the discussion on the NQF and are afraid that the EQF will challenge the Berufsprinzip by leading to a marketization and liberalization of VET (DGB, 2005: 5; Drexel, 2005; Dehnbostel et al., 2009: 18-21).

An influential group engaged in adapting on-going reforms of the German VET system to the EQF and ECVET initiatives-at the expense of trade union influence-is the so-called "Innovation Circle on VET," a new council at the BMBF (Trampusch, 2008; Busemeyer, 2009: 166-9). In addition to the federal government, members of this committee represent trade unions, entrepreneurs, representatives of innovative educational practice, and independent scientists, but not the Federal Institute for VET (Bundesinstitut fur Berufsbildung, BIBB) and its "parliament," the tripartite Main Board (Hauptausschuss) of the BIBB. Thelen and Busemeyer (2007: 27) stress that the Innovation Circle contributes to the "attenuating of the voting and opinion power of potentially obstructionist parties" like the trade unions. With the support of the federal state (Land) of Baden-Wuerttemberg, the BDA introduced its demand for a radical modularization of the German VET system to this circle. The BDA requested that the government order the testing of modules-an initiative that recently failed because of the resistance of a coalition consisting of trade unions and chambers of crafts (Trampusch, 2008). Whereas employers have used the group to further the discourse on modularization, the federal government has instead used it as a device to actively and domestically publicize EU policies. In January 2007, during a meeting to discuss the modularization issue, the Federal Education Minister Annette Schavan demanded that the German VET system must be made EU-compatible (Trampusch, 2009). In the context of the EQF, the federal government has also set up other institutions and thereby circumnavigates the traditionally influential actors like the BIBB. In January 2007, for instance, a "Common Working Group of Federation and Federal States" was established. Finally, a "German Qualifications Framework" working group was founded, in which-alongside the federation and federal states (Länder)—social partners, scientific and educational institutions, and the $\mathrm{BIBB}$ are represented. This trend has been strengthened through 
establishment of a German Qualifications Framework Office that organizes the whole preparation process (Trampusch, 2008: 602).

In the "Europeanized" dynamics of VET policy in Germany, the following point deserves attention: in Germany the NQF process features politics, conflicts, and the active use of government and business power to influence the dynamics of institutional change. The government and large employers have proactively used the EU initiatives to shift the power in VET policy at the expense of union influence. Furthermore, new institutional arrangements in policymaking have partially replaced the traditional "parliament" of German vocational training policy, namely the Main Board of the BIBB, in which the trade unions enjoy strong influence.

\section{Countries of consensus: Austria, Denmark, and the Netherlands}

In contrast to Switzerland and Germany, the cases of Austria, Denmark, and the Netherlands are ones in which the EU initiatives meet reform discussions in progress. The implementation of the NQFs has been relatively consensual, with a lesser degree of politicization and conflict among actors. In these countries, the need for NQFs is expressed by all stakeholders and, thus far, relatively minor conflicts have arisen between actors. In the following, we argue not only that this smooth trajectory mirrors the traditional consensual partnership in the vocational training systems of these countries (for more details, see the respective country chapters in this volume) but also that the NQFs complement ongoing endogenous reform processes which have been undertaken independently from EU initiatives. Thus, in the following we describe the recent steps toward implementation of qualification frameworks and European standards across those collective skill system countries in which we found consensus.

\section{AUSTRIA}

The Austrian collective skill system has a number of characteristics and processes important to the question of Europeanization and its effects in the alpine republic. Ongoing Europeanization processes, especially the Copenhagen Process and the developments of the EQFs and NQFs, call for Austria to facilitate lifelong learning and increase the permeability between educational pathways. However, these demands arise in an era in which domestic actors long ago began incremental processes of change in skill formation, such as a stepwise flexibilization of VET advocated by the government and the social partners to meet the challenges to the dual system through the modernization of apprenticeship trades. Also, examinations, such as the Berufsreifeprïfung, at least officially enable access to higher levels of education (including university) for those who have completed vocational training. The modularization of 
VET should make the dual system more attractive (Trampusch, 2009: 382). A Berufsmatura now even bridges the sectors of VET and HE.

In particular, the modularization of the Austrian VET system has major consequences for our interpretation of the Austrian reactions to the EQF and the process of Europeanization, because in Austria modularization exhibits a quite different trajectory than it does in Germany (Trampusch, 2009: 382-3). First, few conflicts arose among actors because the reform proposal was formulated in consensus among the economic and education ministries and the social partners. Second, modularization serves to reform apprenticeships within traditional dual system principles; thus, the recommended modules are very broadly defined. Consequently, we argue that Austria has incrementally and consensually reformed its VET system, becoming more compatible with the EQF.

How do key Austrian actors perceive the EQF process? Our analysis reveals that there is broad consensus on establishing the Austrian NQF (for the following and further sources, see Trampusch, 2009: 378-9). The work on the NQF began as early as 2006 , and in 2007 the NQF became one of the central themes in education policy. During the consultation process on the EQF agreement, the need for an NQF was expressed by all stakeholders; the same applied to the ECVET consultation process. In the summer of 2006, working groups were already set up to prepare an NQF based on in-depth research, which resulted in an intensive fact-finding phase. In February 2007, a national steering group was constituted to head up a national bottom-up process of consultation commencing in the fall of that year. The government invited all stakeholders to present their interests and positions on the design of the framework by June 2008. To facilitate this process, the Federal Ministry for Education, the Arts, and Culture (Bundesministerium für Unterricht, Kunst und Kultur, BMUKK) and Federal Ministry of Science and Research (Bundesministerium für Wissenschaft und Forschung, BMWF) published a "Consultation Paper NQF for Austria," which was compiled with the help of national VET research institutes. This document not only describes the NQF process in Austria but also presents the stakeholders with a series of detailed questions. The government also suggested that new collective committees be installed that are devoted to managing and administering the Austrian NQF.

The most remarkable feature of the Austrian NQF process is that, despite broad participation, until recently only minor conflicts have arisen between actors (Interviews A2, A3, A4), as all stakeholders regarded the NQF process as an advantage for the national reform discussions (Interview A2). The considerable consensus between and among employers and trade unions distinguishes the Austrian NQF discussion from that in Germany (Interviews A2, A3, A4). Notably, SME view the introduction of an Austrian NQF as a means to strengthen the dual system and to increase its attractiveness vis-à-vis the school-based training schemes (Interview A4). Further, five research institutes 
are involved in the NQF process by writing evaluation reports and delivering research reports on NQF developments in other countries.

While the early period of Copenhagen implementation progressed in traditional, consensual policy style (Trampusch, 2009) and much of the NQF was simply copied from the EQF (Schlögl, 2008), a new debate has arisen on the consequences of fitting vocational and higher education certificates into one qualification framework; some fear the reification of the division between VET and HE through the implementation of parallel levels for these two sectors (see Bernhard et al., 2010: 28). This has led to unease and increasing debate as the process begins to receive more attention among domestic actors. Indeed, education and training policies, among the last remaining vestiges of complete nation-state control, are increasingly of interest to the social partners as this policy field offers opportunities to participate in policymaking, even if these reforms to modernize the skill formation system remain mainly incremental (see Graf, Lassnigg, and Powell in this volume). Nevertheless, the state retains its power over education via relatively centralized educational governance and financing - and attempts to increase its influence on training via participation in the Copenhagen Process.

\section{DENMARK}

Like the German-speaking countries with dual systems, Denmark has a long tradition of apprenticeship. In fact, it is considered a highly successful VET system, distinguished by strong craft unions, equal representation of unions and employer organizations in VET governance, and a supportive state (see Nelson in this volume). The social partners are involved in the crucial aspects of training, from provision and financing to administration. For several decades, continuous reforms have bolstered the proportion of young people who participate in apprenticeship training, with roughly a third of young people in Denmark utilizing that pathway to attain their vocational qualification. Further, VET is seen as a pillar of overall educational provisions for youth as they transition to adulthood and take up citizenship duties (Cort and Wiborg, 2009).

In delineating the resonance between the European and Danish VET policies, Pia Cort $(2009,2010 b)$ has argued that, while tensions between the Danish government, specifically the Ministry of Education, and the social partners have been accentuated by the Copenhagen Process, the introduction and implementation of an NQF has been accomplished without open conflict. She reports an incremental process of increasing influence of the European level on national institutions, signaled prominently when the European standardization initiative in VET was named the "Copenhagen Process" during the Danish presidency of the EU in 2002 and reflected in the twin aims of global economic competitiveness via high-skill strategies and the strengthening of social cohesion. 
Thus far, in Denmark, no offensive has evolved to question the process of setting up a qualification framework based on the EQF model (Interview DK1). Indeed, all political parties support the NQF, even if a different name- "qualifications key" - was used originally for the Danish version to reduce the potential resistance to these European standards by the political opposition, especially that of the Danish Conservative People's Party (Cort, 2010b). As is so often the case, the strategic naming of a reform can help reduce opposition. As in many other countries in Europe, public awareness of the Copenhagen Process lags behind the other major process of Europeanization of skill formation, such that political actors can move forward without the media wakefulness, and resulting dialogue, accorded to the Bologna Process.

Turning to the social partners, both trade unions (Danish Confederation of Trade Unions, LO) and employers (Danish Employers' Confederation, DA) ascribe overarching goals to the European level that are beyond criticism and almost universally viewed in positive terms, such as increased transparency, mutual recognition, and mobility (Cort, 2010b). A crucial point is that the EQF is seen to be voluntary and to provide useful tools to deal with ubiquitous problems, which reduces the concern or outright resistance to implementation (Cort, 2010b). Over time, the process of European VET policy development traced above has been taken for granted, to the point that modernization and improvement are often identified with European programs-and thus difficult to wholly block. However, in Denmark as elsewhere, one area of open conflict is the placement of certain vocational qualifications into the levels of the NQF, thereby establishing a hierarchy that, by its very nature, produces winners and losers. The EQF legitimizes the use of such frameworks within countries to define, evaluate, and structure initial vocational training programs and certificates-a process that has long divided interest groups involved in skill formation.

In sum, EU policies on VET, especially the EQF, have become translated and ingrained in the Danish collective skill regime, and the NQF has been accepted by all major stakeholders. Europeanization, as a long line of incremental steps, has increased its relevance and influence in Denmark. However, the new focus on learning outcomes instead of largely implicit contents has nevertheless required the active reshaping of national policies-providing the Ministry of Education with opportunities to gain influence by shepherding this process forward. Thus, within Denmark there is a parallel increase of executive authority to that of the EC deriving from its large-scale attempts to establish quality assurance, facilitate standardization and fund mobility across Europe and beyond.

\section{THE NETHERLANDS}

While VET has traditionally been more school-based in the Netherlands than in Germany, apprenticeship has risen following a restructuring of vocational 
education in 1996, with approximately a third of a cohort entering such a program (Maes, 2004). This renewed emphasis on workplace-based learning responds to critiques of the preparation provided in state-funded and regulated vocational schools. To gauge contemporary developments resulting from Europeanization, the impact of the 1996 Education Act is important because it shifted attention toward an outcome-based and modularized qualification system, which is now advocated strongly within the Copenhagen Process, and for the first time legally joined the previously divided responsibilities for skill formation shouldered by the state and the social partners, specifically for school-based and in-firm VET, respectively (see Anderson and Oude Nijhuis in this volume).

Other national developments include the extension of compulsory schooling to age 18 (and the emphasis on attaining a qualification at level two of the national qualification structure) and the founding of Knowledge Centers (Kenniscentra, KCs) to certify skills and recognition of prior learning. A reduction by half of the number of vocational qualifications, from 600 to 300 , aims to enhance flexibility and to advance individual career preparation and "knowledge-based employability," while retaining the comprehensive vocational preparation (Brockmann et al., 2008) characteristic of all collective skill systems. Thus, as in Austria and to some extent Denmark, the Netherlands had already begun moving in the direction of skill formation reform favored in Europe in the decade prior to 2002. However, defining NQFs should not be equated with wholesale approval or implementation of outcome- and skillbased training, as in collective skill regimes the understanding of competence refers not to individual performance in the firm (as in liberal market economies), but rather to a more holistic perspective on individuals with both theoretical knowledge and practical experience.

Thus far, the Europeanization of skill formation in the Netherlands can be seen in the implementation of Europass (as of 2005) and in the issuance of diploma and certificate supplements. Yet, in terms of translating the $\mathrm{EQF}$ into an NQF, there has only been modest progress in involving the public and private sectors in the reform process (Visser, 2010). Some attribute this to the "predominant opinion" that the Netherlands simply does not need-or want-a new NQF that responds to and implements the EQF instead of its own national framework (Transeqframe, 2005). Others believe that, without more attention to the EQF and its national variant, the successful implementation of ECVET will also remain tenuous, even if the division between the ECVET and the European Credit Transfer System (ECTS) is viewed critically. Nevertheless, the Netherlands has actively participated in the Copenhagen Process without major conflicts owing to the similar direction of exogenous and endogenous developments. 
In the Netherlands, the "plurality of aims is reflected in a plurality of stakeholders in vocational education" (Westerhuis, 2007: 31). These stakeholders, from labor to educational associations to employers, have stated that they have little reason not to support Europeanization efforts because such qualification frameworks are viewed as tools by which to compare or match skills and to assure quality. However, principles of identification and validation of nonformal and informal learning remain more controversial (see Transeqframe, 2005). For its significant part, the Ministry of Education's policy has been to base EQF implementation on the Netherlands' existing qualification system, with the NQF primarily serving since 2007 (inspired by the panEuropean Copenhagen Process) to relate those national qualification standards to the European level. Thus far, such usage and the Copenhagen Process in general seem to provoke little resistance or even concern, because the defined goals remain general and abstract and legitimation arguments are so diverse as to give everyone something they can favor (Powell et al., forthcoming).

In the Netherlands, as in other collective skill regimes, EU policies for VET, in particular the $E Q F$, have modestly influenced recent developments, yet these specific initiatives have not been implemented wholesale because endogenous interests and developmental processes are acceded far more importance. Inasmuch as European and national developments tend to head in the same direction, European influence can be overestimated. Time and further research are needed to differentiate conclusively the European from the national influence in a country with a binary VET system that has long supplied its highly globalized economy with the needed skills to compete in international markets.

\section{Comparing countries}

When we compare these different countries, which factors account for the conflicts over the EU initiatives and the NQFs in Germany and Switzerland and the consensus on them in Austria, Denmark, and the Netherlands? Based on our analysis, one hypothesis would be that the existence of conflict or consensus may largely depend on the balance of power between reform and conservative coalitions at national level and on national reforms made before and independently of the EU initiatives. ${ }^{7}$ In the countries of conflict, the balance of power is distributed unequally, with NQF reformers met by opponents; and modularization is contested. In Switzerland and Germany, there are actors who actively support the NQFs: in Germany, this is the coalition of large employers, the BDA, and the BMBF. In Switzerland, these are the BBT and those segments of the business community that view the increasing (geographical) mobility of apprentices as coalescing with their firms' interests because they recruit staff from abroad. Furthermore, in both countries, 
important domestic actors have opposed the introduction of an NQF: in Switzerland, the Gewerbe, and in Germany, trade unions. This evidence signifies that, in both countries, there are actors who clearly view the NQF as a threat to the traditional collective skill formation system. The opposition of the Swiss Gewerbe and of German trade unions against the NQFs mirrors the peculiarities of these systems, embedded within particular political situations (see Gonon and Maurer in this volume; Thelen and Busemeyer in this volume). Whereas the Swiss system is employer-dominated and trade unions play a marginal role, in Germany the chambers of crafts and the trade unions are strongly involved in vocational training. Opposition comes mainly from those actors who are in the position of a "private interest government" in the respective training systems. In addition, the German case shows that the federal authorities and large employers can overcome the resistance of unions and craft chambers, whereas in Switzerland the BBT's failure illustrates well the different positions of the state in the two countries. In Switzerland, the federation has far less power than in Germany because there is not yet a federal education ministry. Furthermore, the different policy positions of Swiss firms, depending on their economic sector, also help to explain the slow speed of the Swiss NQF preparation process.

By contrast, the other collective skill system countries-Austria, Denmark, and the Netherlands-have witnessed far less conflict and enjoyed far more consensus, which has been the hallmark of national responses to Europeanization of skill formation. On the basis of our case studies, it seems reasonable to argue that consensus and fewer conflicts are more likely if the balance of power is equally distributed (as in Austria and Denmark) and where there is a clearly dominant player (the state in the Netherlands). Furthermore, because these countries had already begun moving in the direction of skill formation reforms favored in Europe during the decade prior to 2002, recent pan-European initiatives have strengthened the national-level trajectories and dynamics.

\section{Conclusion}

The strengthened role of international organizations and multilevel governance in education policy requires increased attention to European and national education policymaking, especially on how international initiatives affect national skill formation systems (Powell and Solga, 2010, Busemeyer and Trampusch, 2011). We have shown that advancing Europeanization of skill formation over the postwar period, and especially over the past decade, has elicited varying responses among the collective skill system countries. Determined by national contexts in which we find a range of collaborative efforts, even consensus, as well as 
explicit and continuing conflicts, the impact of Europeanization, and the EU in particular, has been far from uniform.

The effects of the European level on national institutions responsible for skill formation-measured in reactions to the deliberation and implementation process of qualification frameworks-have led to different responses in collective skill systems. If Switzerland showed the most resistance to the implementation of an NQF, in Germany this process also led to hesitance among significant interest groups. By contrast, Austria, Denmark, and the Netherlands each found less to criticize, especially given advances made during endogenous reformsas well as their continuing deference to Europe. In sum, even within this select group of countries, there is a cleavage between those countries in which European initiatives are largely accepted and even legitimate ongoing endogenous reform processes and those in which national interest groups and collective actors resist or vociferously debate these exogenous pressures and international developments.

Our case studies have shown that the dynamics of Europeanization mirror significant differences found in these five collective skill formation systems. In Germany and Switzerland, the opposition of those actors active in "private interest government" leads to conflictual NQF formulation processes. The active role of the state facilitated the overcoming of resistance in Germany. In Switzerland, the federal level is far less powerful, specifically because it lacks a federal education ministry. The consequence is stalemate in the NQF process. By contrast, in Austria, Denmark, and the Netherlands, we found a more consensual path. Such accord reflects the traditional consensus-oriented policy style in these countries. However, these cases also show that linking the NQFs for higher education and vocational training together in one framework may result in conflicts at the implementation stage, as in the case of Austria. Whether the future will bring more consensual or more conflictual dynamics depends largely on the actor constellations at national level as well as the evolution of national reform processes (analyzed in the country chapters in this volume).

These ongoing processes on multiple levels of governance seem likely to call forth more resistance as we move closer to implementation, especially if the Copenhagen Process reaches the level of awareness and dialog accorded to the more advanced pan-European initiative in $\mathrm{HE}$, the Bologna Process. Ironically, European-level initiatives and programs in VET were a hallmark of EU policy from the very beginning, but it was HE systems, even within collective skill regimes, that have thus far more rapidly and completely implemented European standards. As we have shown, with elaborated NQFs, these two processes of Europeanization have moved closer together. Whether their implementation will have similar effects on the relationship between the two sectors 
of skill formation systems-higher education and vocational training-will depend on the evolving national dynamics of change.

\section{Endnotes}

1. We would like to thank Marius Busemeyer, Lukas Graf, and Anja P. Jakobi for their comments. At the request of interview partners, interviews with experts and actors in the field are cited only in code form. The interviews were carried out between 2008 and 2010.

2. According to Eckstein (1975), "least likely" cases are particularly helpful to confirm theoretical expectations. Least likely cases allow "Sinatra inference" (Levy, 2002: 44 ), which, when applied to collective skills systems, suggests that Europe is even more likely to affect others if the EU significantly affects these training systems.

3. Please note that we do not follow common causal conceptions of Europeanization that only capture the increasing influence of $\mathrm{EU}$ policies on national policies and politics. Instead, in line with Trampusch (2009), we perceive the concept of Europeanization as an outcome-oriented heuristic device in order to explore processes of institutional change resulting in a situation that mirrors EU policy. This concept does not argue that any EU initiative picked up by domestic actors is "Europeanization." Rather, it differentiates between exogenous (EU) and endogenous (domestic) factors of institutional change and analyzes their interplay in those Europeanization processes, including the unintended consequences that extend beyond multilevel games and Europeanized national reform politics. Such a perspective links Europeanization research to larger themes in comparative politics, like institutional change or the literature on varieties of capitalism.

4. Switzerland is not covered by the CEDEFOP reports.

5. The Swiss Gewerbe includes a large number of small enterprises, which are characterized by a high share of family ownership, personnel-intensive units, and a strong orientation toward domestic markets. It includes, for example, construction, retail trade, meat processing, and milk processing.

6. The SGV (Schweizerischer Gewerbeverband; Swiss Trade Association) represents the interests of the SME of the traditional craft sector (Gewerbe).

7. Here, we largely follow Trampusch (2009), but we thank Marius Busemeyer for reminding us.

\section{References}

Arbeitskreis Deutscher Qualifikationsrahmen (AK DQR) (2009). Discussion Proposal for a German Qualifications Framework for Lifelong Learning. Prepared by the German Qualifications Framework Working Group, http:// www.deutscherqualifikationsrahmen.de (accessed December 2, 2010). 
Antonelli Müdespacher, L. (2010). Europäische Zusammenarbeit als Chance für die Positionierung der höheren Berufsbildung. Berne: BBT, http://www.bbt.admin.ch (accessed December 2, 2010).

Baethge, M., Solga, H. and Wieck, M. (2007). Berufsbildung im Umbruch. Berlin: Friedrich-Ebert-Stiftung.

_- Achtenhagen, F. and Arends, L. (2008). "How to Compare the Performance of VET Systems in Skill Formation." In K.U. Mayer and H. Solga, eds., Skill Formation: Interdisciplinary and Cross-National Perspectives. Cambridge: Cambridge University Press, 230-54.

Balzer, C. and Rusconi, A. (2007). "From the European Commission to the Member States and Back? A Comparison of the Bologna and Bruges-Copenhagen Processes." In K. Martens, A. Rusconi and K. Leuze, eds., New Arenas of Educational Governance. Houndsmills: Palgrave, 57-75.

Bernhard, N., Graf, L. and Powell, J.J.W. (2010). "Wenn sich Bologna und Kopenhagen treffen. Erhöhte Durchlässigkeit zwischen Berufs- und Hochschulbildung." WZB Mitteilungen 130: 26-9.

Bieber, T. (2010). "Europe à la Carte? Swiss Convergence towards European Policy Models in Higher Education and Vocational Education and Training." In M.R. Busemeyer and C. Trampusch, eds., Berufsbildungs- und Hochschulpolitik in der Schweiz, Österreich und Deutschland. Special issue. Swiss Political Science Review 16(4): 773-800.

Borrás, S. (2009). "The Politics of the Lisbon Strategy: The Changing Role of the Commission." West European Politics 32(1): 97-118.

Börzel, T.A. (2005). "Europeanization: How the European Union Interacts with its Member States." In S. Bulmer and C. Lequesne, eds., Member States and the European Union. Oxford: Oxford University Press, 45-69.

Brockmann, M., Clarke, L. and Winch, C. (2008). "Knowledge, Skills, Competence: European Divergences in Vocational Education and Training (VET)-The English, German and Dutch Cases." Oxford Review of Education 34(5): 547-67.

Büchs, M. (2008). "The Open Method of Coordination as a 'Two-Level Game.'" Policy \& Politics 36(1): 21-37.

Bundesamt für Berufsbildung und Technologie (BBT) (2009a). Der KopenhagenProzess-in Kürze. http://www.bbt.admin.ch (accessed December 2, 2010).

$-(2009 \mathrm{~b})$. European Credit System for Vocational Education and Training (ECVET)-In Kürze. http://www.bbt.admin.ch (accessed December 2, 2010).

Bundesministerium für Bildung und Forschung (BMBF) (2010). DECVET-Development of a Credit System for Vocational Education and Training in Germany, http://www .decvet.net/en/Home/site_2 (accessed December 2, 2010).

Busemeyer, M.R. (2009). Wandel trotz Reformstau: Die Politik der beruflichen Bildung seit 1970. Frankfurt a.M.: Campus.

- Trampusch, C. (2011). "Comparative Political Science and the Study of Education." British Joumal of Political Science 41(2): 413-33.

Copenhagen Declaration (2002). Declaration of the European Ministers of VET and the EC Convened in Copenhagen on November 29 to 30, 2002, http://ec.europa.eu/ education/vocational-education/doc1143_en.htm (accessed January 17, 2011). 
Cort, P. (2009). "The EC Discourse on Vocational Training." Vocations and Learning 2 (2): 87-107.

- $(2010 a)$. "Stating the Obvious: The European Qualifications Framework Is Not a Neutral Evidence-Based Policy Tool." European Educational Research Journal 9(3): 304-16.

- $(2010 b)$. "Europeanization and Policy Change in the Danish VET System." Research in Comparative and International Education 5(3): 331-43.

CRUS, KFH, co-hep (2009). Qualifikationsrahmen für den schweizerischen Hochschulbereich nqf.ch-HS vom gemeinsamen Leitungsausschuss der drei Rektorenkonferenzen (la-rkh.ch) z.H. des Staatssekretariats für Bildung und Forschung verabschiedet am 23. November 2009.

Dehnbostel, P., Neß, H. and Overwien, B. (2009). Der Deutsche Qualifikationsrahmen (DQR)-Positionen, Reflexionen und Optionen: Gutachten im Auftrag der Max-TraegerStiftung. Frankfurt: GEW, http://www.gew.de/Binaries/Binary53775/DQR-Gutachten.pdf (accessed December 2, 2010).

Deißinger, T. (1994). "The Evolution of the Modern Vocational Training Systems in England and Germany: A Comparative View." Compare 24(1): 17-36.

Deutscher Gewerkschaftsbund [DGB] (2005). Stellungnahme des Deutschen Gewerkschaftsbundes (DGB) zum Konsultationsprozess, http://ec.europa.eu/education/policies/educ/eqf/results/dgb_de.pdf (accessed December 2, 2010).

Drexel, I. (2005). Das Duale System in Europa. http://www.igmetall-wap.de/publicdownload/Gutachten_Drexel.pdf (accessed December 2, 2010).

Eckstein, H. (1975). "Case Study and Theory in Political Science." In F. Greenstein and N. Polsby, eds., Handbook of Political Science. Boston: Addison-Wesley, 79-138.

ECVET (2010). European Credit System for Vocational Education and Training. http:// www.ecvet.de/c,php/ecvetde/ecvet_inhalt/info.rsys (accessed December 2, 2010).

European Centre for the Development of Vocational Training (CEDEFOP) $(2009,2010)$. The Development of National Qualifications Framewarks in Europe. Luxembourg: Publications Office of the European Union.

European Council (2000). Presidency Conclusions. http://www.consilium.europa.eu/uedocs/cms_data/docs/pressdata/en/ec/00100-r1.en0.htm (accessed December 2, 2010).

- (2003). Presidency Conclusions. http://www.consilium.europa.eu/uedocs/cms data/docs/pressdata/en/ec/75136.pdf (accessed December 2, 2010).

Falkner, G., Treib, O., Hartlapp, M. and Leiber, S. (2005). Complying with Europe. Cambridge: Cambridge University Press.

Gillingham, J.R. (2003). European Integration, 1950-2003. Cambridge: Cambridge University Press.

Hanf, G. and Rein, V. (2006). "Nationaler Qualifikationsrahmen-eine Quadratur des Kreises?" BWPAT 11: 1-19. http://www.bwpat.de/ausgabe11/hanf_rein_bwpat11. shtml (accessed December 2, 2010).

Kaufmännischer Verband Schweiz (KV-Schweiz) (2005). Stellungnahme des Kaufmännischen Verbandes Schweiz zur Arbeitsunterlage der EU-Kommission "Auf dem Weg zu einem europäischen Qualifikationsrahmen für Lebenslanges Lernen." http:// www.kvschweiz.ch/graphics/Synkron-Library/Allg_kurzfristiges/StellungnahmeEQF-KVSchweiz.doc (accessed May 5, 2008). 
Kraus, K. (2007). "Die 'berufliche Ordnung' im Spannungsfeld von nationaler Tradition und europäischer Integration." Zeitschrift für Pädagogik 53(3): 382-98.

Kuda, E. and Strauß, J. (2006). "Europäischer Qualifikationsrahmen: Chancen oder Risiken für Arbeitnehmer und ihre berufliche Bildung in Deutschland?" WSI Mitteilungen 59(11): 630-7.

Levy, J.S. (2002). "Qualitative Methods in International Relations." In F.P. Harvey and M. Brecher, eds., Evaluating Methodology in International Studies. Ann Arbor: University of Michigan Press, 432-54.

Linder, W. (2011). "Europe and Switzerland: Europeanization without EU-membership." In C. Trampusch and A. Mach, eds., Switzerland in Europe: Continuity and Change in the Swiss Political Economy. London and New York: Routledge, 43-59.

Longpré, M. (2007). "TransEQFrame: WP3 Intermediate Report-Switzerland." Berne: Federal Office for Professional Education and Technology, http://www.transeqframe. net/Report_and_outcomes/Policy/National\%20reports/policy_nr_su.pdf (accessed December 2, 2010).

Maes, M. (2004). Vocational Education and Training in the Netherlands: Short description. Rev. edn. CEDEFOP Panorama series 96. Luxembourg: Office for Official Publications of the European Communities.

Mahoney, J. (2004). "Comparative-Historical Methodology." Annual Review of Sociology 30: 81-101.

Mastenbroek, E. and Kaeding, M. (2006). "Europeanization Beyond the Goodness of Fit: Domestic Politics in the Forefront." Comparative European Politics 4(4): 331-54.

Meyer, S. (2010). "Der Kopenhagen-Prozess in der Schweiz. Konflikte um die Errichtung eines Nationalen Qualifikationsrahmens." Unpublished manuscript. University of Berne.

Münch, R. (2009). Globale Eliten, lokale Autoritäten: Bildung und Wissenschaft unter dem Regime von PISA, McKinsey \& Co. Frankfurt a.M.: Suhrkamp.

Olsen, J.P. (2002). "The Many Faces of Europeanization." Journal of Common Market Studies 40(5): 921-52.

Pevec Grm, S. and Bjørnåvold, J. (2010a). "Development of National Qualifications Frameworks (NQFs) in Europe." EQF Newsletter April: 9.

_- $(2010 b)$. "Development of National Qualifications Frameworks (NQFs) in Europe: Cedefop Overview-June 2010." EQF Newsletter July: 6-7.

Powell, J.J.W. and Solga, H. (2010). "Analyzing the Nexus of Higher Education and Vocational Training in Europe: A Comparative-Institutional Framework." Studies in Higher Education 35(6): 705-21.

(2011). "Why Are Participation Rates in Higher Education in Germany So Low? Institutional Barriers to Higher Education Expansion." Journal of Education and Work 24(1): 49-68.

- Bernhard, N. and Graf, L. (forthcoming). The Emergent European Model in Skill Formation: Comparing Higher Education and Vocational Training in the Bologna and Copenhagen Processes. Sociology of Education.

Putnam, R.D. (1988). "Diplomacy and Domestic Politics: The Logic of Two-Level Games." International Organization 42(1): 121-48. 
Radaelli, C.M. (2000). "Whither Europeanization? Concept Stretching and Substantive Change." European Integration Online Papers 4(8), http://eiop.or.at/eiop/texte/2000008a.htm (accessed December 15, 2010).

- (2004). "Europeanization: A Solution or Problem?" European Integration online Papers 8(16), http://eiop.or.at/eiop/pdf/2004-016.pdf\#search=\%22\%22Europeanization\%3A \%20Solution \%20or\%20Problem\%3F\%22\%22 (accessed December 2, 2010).

Schavan, A. (2008). Der Deutsche Qualifikationsrahmen für Lebenslanges Lernen: Erwartungen und Herausforderungen. http://www.bmbf.de/pub/mr_20080305.pdf (accessed December 2, 2010).

Schläfli, A. (2010). Der EQR und das modulare System. Presentation at the ModuQua conference, Zurich, Switzerland, http://www.moduqua.ch/images/pdfs/andr\% E9_sch1\%E4fli_moduqua_1_4_2010.pdf (accessed December 2, 2010).

Schlenczek, G. (2009). "Kopenhagen-Prozess: Die Zeit drängt." htr hotel revue 43: 9. http://www.htr.ch/fokus/kopenhagen-prozess-die-zeit-draengt-17000.html (accessed December 2, 2010).

Schlögl, P. (2008). "Perspektiven des nationalen Qualifikationsrahmens in Österreich: Vertikale Durchlässigkeit und Anerkennung informellen Lernens." In $\mathrm{H}$. Neß and T. Kimmig, eds., Kompendium zu aktuellen Herausforderungen beruflicher Bildung in Deutschland, Polen und Österreich. Frankfurt a.M.: DIPF, 94-7.

Schneider, S.L., ed. (2008). The International Standard Classification of Education (ISCED-97): An Evaluation of Content and Criterion Validity for 15 European Countries. Mannheim: Mannheimer Zentrum für Europäische Sozialforschung.

Severing, E. (2005). "Europäische Zertifizierungsstandards in der Berufsbildung." Zeitschrift für Berufs- und Wirtschaftspädagogik, Supplement 3(5): 1-22.

Solga, H. (2008). "Lack of Training." In K.U. Mayer and H. Solga, eds., Skill Formation: Interdisciplinary and Cross-National Perspectives. New York: Cambridge University Press, 173-204.

Stalder, M. (2006). "Der Kopenhagen-Prozess und die Schweiz." Die Volkswirtschaft. Das Magazin für Wirtschaftspolitik 3: 59-62.

Thelen, K. and Busemeyer, M.R. (2007). From Collectivism toward Segmentalism: Skill Regimes and Trends in German Vocational Training. Paper presented at the SASE conference, Copenhagen, Denmark.

Trampusch, C. (2008). "Jenseits von Anpassungsdruck und Lernen: Die EU-Berufsbildungspolitik und die Europäisierung der deutschen Berufsbildungspolitik." Zeitschrift für Staats- und Europawissenschaften 6(4): 577-605.

- (2009). "Europeanization and Institutional Change in Vocational Education and Training in Germany and Austria." Governance 22(3): 369-95.

- (2010). "The Politics of Institutional Change: Transformative and Self-Preserving Change in the Vocational Education and Training System in Switzerland." Comparative Politics 42(2): 187-206.

Transeqframe (Trans-European Qualifications Framework Development) (2005). Country Report WP 3: The Netherlands. http://www.transeqframe.net/Report_and_outcomes/Policy/National\%20reports/policy_nr_nl.pdf (accessed December 2, 2010). 
Visser, K. (2010). Overview of the Dutch Vocational Education and Training System. ReferNet Country Report 8 (Autumn). 's-Hertogenbosch: ECBO (Centre for Expertise in Vocational Education and Training).

Walkenhorst, H. (2008). "Explaining Change in EU Education Policy." Journal of European Public Policy 15(4): 567-87.

Westerhuis, A. (2007). "The Role of the State in Vocational Education: A Political Analysis of the History of Vocational Education in the Netherlands." In L. Clarke and C. Winch, eds., Vocational Education: International Approaches, Developments and Systems. London: Routledge, 21-33.

Wiborg, S. and Cort, P. (2009). "The VET System in Denmark." In G. Bosch and J. Charest, eds., Vocational Training. London: Routledge, 84-109.

Witte, J., van der Wende, M. and Huisman, J. (2008). "Blurring Boundaries: How the Bologna Process Changes the Relationship between University and Non-University Higher Education in Germany, the Netherlands and France." Studies in Higher Education 33(3): 217-31.

Woll, C. and Jacquot, S. (2008). Strategic Action in the European Union. Paper presented at the ECPR joint sessions workshop "Does European Integration Theory Need Sociology?" Rennes, France.

Woortmann, G. (2006). "Alte Denkmuster verlassen: Überlegungen zur Entwicklung einer attraktiven und EU-kompatiblen Aus- und Weiterbildung." Berufsbildung in Wissenschaft und Praxis 35(5): 54-7. 


\section{The Political Economy of Collective Skill Formation}

Edited by

Marius R. Busemeyer and Christine Trampusch

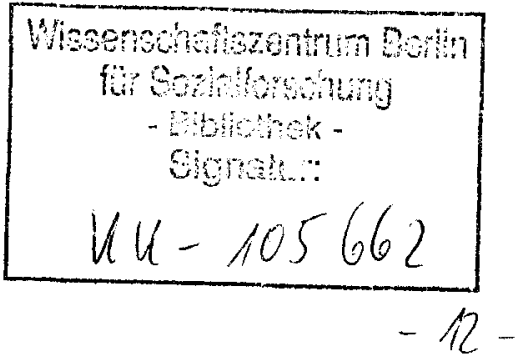




\section{OXFORD}

UNIVERSITY PRESS

Great Clarendon Street, Oxford ox2 6DP

Oxford University Press is a department of the University of Oxford.

It furthers the University's objective of excellence in research, scholarship, and education by publishing worldwide in

Oxford New York

Auckland Cape Town Dar es Salaam Hong Kong Karachi

Kuala Lumpur Madrid Melbourne Mexico City Nairobi

New Delhi Shanghai Taipei Toronto

With offices in

Argentina Austria Brazil Chile Czech Republic France Greece

Guatemala Hungary Italy Japan Poland Portugal Singapore

South Korea Switzerland Thailand Turkey Ukraine Vietnam

Oxford is a registered trade mark of Oxford University Press

in the UK and in certain other countries

Published in the United States

by Oxford University Press Inc., New York

(c) Oxford University Press 2012

The moral rights of the authors have been asserted

Database right Oxford University Press (maker)

First published 2012

All rights reserved. No part of this publication may be reproduced, stored in a retrieval system, or transmitted, in any form or by any means, without the prior permission in writing of Oxford University Press, or as expressly permitted by law, or under terms agreed with the appropriate reprographics rights organization. Enquiries concerning reproduction outside the scope of the above should be sent to the Rights Department, Oxford University Press, at the address above

You must not circulate this book in any other binding or cover and you must impose the same condition on any acquirer

British Library Cataloguing in Publication Data

Data available

Library of Congress Cataloging in Publication Data

Data available

Typeset by SPI Publisher Services, Pondicherry, India

Printed in Great Britain

on acid-free paper by

MPG Books Group, Bodmin and King's Lynn

ISBN 978-0-19-959943-1

13579108642 